\title{
A SYSTEMATIC REVIEW OF NEUROIMAGING STUDIES OF DEPRESSION IN ADULTS WITH EPILEPSY
}

\section{${ }^{1}$ Samia Elkommos and ${ }^{1,2}$ Marco Mula}

${ }^{1}$ Atkinson Morley Regional Neuroscience Centre, St George's University Hospitals NHS Foundation Trust, London, United Kingdom

${ }^{2}$ Institute of Medical and Biomedical Education, St George's University of London, United Kingdom

\section{Correspondence:}

Marco Mula MD PhD FRCP FEAN

Atkinson Morley Regional Neuroscience Centre

St George's University Hospitals NHS Foundation Trust

Blackshaw Road

London SW17 0QT

United Kingdom

Tel. +442087254322

Fax +442087254591

Email:mmula@sgul.ac.uk

Word count for the abstract: 232; Word count for the paper: 4090; Number of references: 81 ; Number of tables: 1; Number of figures: 1 


\begin{abstract}
Objective: Depression is a relatively common comorbidity in people with epilepsy with a lifetime history identified in 1 in 4 individuals. In this paper, we aim to provide a systematic review of structural and functional brain region-specific group differences of adults with epilepsy and depression and to discuss existing evidence as compared to that in people with depression.
\end{abstract}

Methods: We undertook a systematic review of neuroimaging studies of depression in adults with epilepsy through MEDLINE/PubMed, Embase and PsycInfo searches until June 2020.

Results: A total of 44 studies were included in the qualitative synthesis: 21 on structural neuroimaging, 9 on functional and 14 on pharmaco/metabolic neuroimaging. Almost all studies focused on temporal lobe epilepsy (TLE). Patterns of changes in the hippocampi and subcortical structures seem to be different from those reported in depression outside epilepsy. Cortical changes are grossly similar as well as the lack of any laterality effect. Serotonin dysfunction seems to be due to different mechanisms with reduced synaptic availability for depression in epilepsy as compared to reduced 5HT1 receptor density outside epilepsy. Depressive symptoms seem to correlate with a dysfunction in temporolimbic structures contralateral to the epileptogenic zone especially in patients with de novo post-surgical depression.

Conclusions: Depression, at least in TLE, seems to be associated with a different pattern of brain changes as compared to major depression, potentially supporting the notion of phenomenological peculiarities of depression in epilepsy.

Key words: epilepsy, depression, neuroimaging, serotonin, temporal lobe 


\section{INTRODUCTION}

Depression is a relatively frequent comorbidity in people with epilepsy, with a lifetime history identified in one of every four individuals [1]. A meta-analysis of 14 populationbased studies including over 1,000,000 participants showed an overall prevalence of active (current or last 12 months) depression in epilepsy of $23.1 \%$ (95\% CI $20.6 \%-28.3 \%$ ) with an increased overall risk of 2.7 (95\% CI 2.09 - 3.6) compared with the general population [2].

The complex relationship between epilepsy and depression was well known since ancient times [3] but more recently, it became apparent that these two conditions have a complex and bidirectional relationship $[4,5]$. The nature of such a relationship seems to be based on quite a solid neurobiological ground apart from psychosocial reasons. Studies in animal models of epilepsy or depression have shown a number of neurobiological changes which can be responsible for both conditions including low serotonin levels [6-8], the reduction in CA3 neuronal cells in the dentate gyrus [9] and the acceleration of the kindling process by high cortisol levels [10]. The connection between epilepsy and depression is also suggested by the role of depression on the outcome of the seizure disorder. In fact, depression in epilepsy is associated not only with poor quality of life [11] but also with antiepileptic drug-resistance $[12,13]$, increased seizure severity [14], increased side effects of anti-seizure medications (ASMs) [15], increased risk of accident and injuries [16], poor outcome after epilepsy surgery [17] and increased mortality [18].

From a neuroanatomical perspective, it is often highlighted that the link between epilepsy and depression is based on the involvement of shared networks comprising mesotemporal structures [19]. During the last few decades, neuroimaging studies have provided insights into brain structural alterations in people with depression without epilepsy, including decreased hippocampal volumes [20], decreased cortical thickness in the frontal lobes and decreased glial/neuronal cell density in the cingulate gyrus, rostral and caudal orbitofrontal cortex and dorsal prefrontal cortex [21,22]. Studies in epilepsy have identified similar areas and networks but data are scattered. In this paper, we aim to provide a systematic review of structural and functional brain region-specific group differences of adults with epilepsy and depression and to discuss existing evidence as compared to that in people with depression.

\section{METHODS}

This systematic review was conducted and reported according to the Preferred Reporting Items for Systematic Reviews and Meta-Analyses (PRISMA) statement. A PROSPERO protocol was developed and registered with registration number CRD42020197868.

A systematic database research on MEDLINE/PubMed, Embase and PsycInfo was conducted using the terms "depression or dysthymia or dysphoria or dysphoric AND epilepsy AND neuroimaging or magnetic resonance or MRI or MRS or positron emission tomography or PET or single photon emission computed tomography or SPECT or single photon emission tomography or SPET ". The search focused on original articles published until $1^{\text {st }}$ June 2020. Inclusion criteria included only human studies of adult participants with any epilepsy diagnosis, depression symptomatology/diagnosis through any means including structured interviews, self-reported symptom scales or a combination of multiple methods. We excluded animal studies, as well as conference abstracts or proceedings. We further examined the reference list of all studies meeting our inclusion criteria to find relevant studies not directly identified by the search terms.

For included studies the following data were extracted: imaging technique (MRI, fMRI, MRS, PET, SPECT), publication details (publication names, authors, year of publication, 
journal, and country), medication status of sample (\% medicated and medications included), sample size, demographic characteristics of sample (age, sex), epilepsy type and diagnosis, seizure frequency, depression diagnosis and assessment, main findings. The authors assessed quality and risk of bias for each included study and disagreements were resolved with discussion. Heterogeneity of studies will be assessed by examining the proportion of studies (specific patient groups and/or particular type of paradigm) contributing to the significance of specific clusters.

\section{RESULTS}

The query revealed 635 results following removal of duplicates, 296 conference abstracts were then removed, and 274 entries were also removed, as they were not pertinent or relevant to the topic of this review (Figure 1). We included 44 studies in our systematic review. Qualitative synthesis of included studies is available in Table 1. We identified three major groups according to the methodology used: 21 structural, 9 functional and 14 pharmaco/metabolic neuroimaging studies. One study was a MRI-PET study providing structural as well as metabolic data but it was counted only once and it is presented in the structural section of Table 1.

\section{STRUCTURAL NEUROIMAGING}

There has been variation in findings from studies examining neuroimaging correlates of depression in patients with epilepsy.

Quiske [23] first suggested an association between depression rating scores and hippocampal sclerosis (HS) and subsequent authors investigated the relationship between laterality of HS and depression with studies supporting either right [24] or the left [25]. Subsequent authors pointed out that probably there is not a laterality effect and even the association between HS and depression was questioned with an equal number of studies showing an association [26] and other authors finding no association between depression and HS [27-29]. The association between depression and the presence of structural abnormalities in the temporal area was then questioned. Adams [30] showed higher incidence of depression in non-lesional focal epilepsies as compared to lesional ones and, more recently, Rayner [31] showed no difference in depression in patients with TLE and HS, TLE and lesions other than HS and MRI-negative TLE, suggesting that mood dysfunction in TLE is not dependent on macroscopic lesions but could be due to underlying network abnormalities.

Some studies have specifically looked at volumetric measurements of the hippocampus and amygdala and the relationship of this to depression in those with TLE. Shamim [32] and Baxendale [25] found that in those patients with right TLE and depression (regardless of whether HS was present) there were also reduced contralateral (left) hippocampal volumes compared to patients without concomitant depression. However, this finding was not replicated in a later study by Hecimovic et al 2014 [33] who found larger hippocampal volumes in those patients with TLE and depression compared to those without depression. Richardson and collaborators [34] found larger amygdala volumes in patients with TLE and depression as compared to patients without depression. Similarly, Van Elst [35] found enlarged left and right amygdala volumes in patients with TLE and dysthymia as well as a significant positive correlation between left amygdala volumes and Beck Depression Inventory (BDI) scores. However, a later study by the same authors [36] found reduced amygdala volumes in patients with epilepsy and concomitant dysphoric disorder, when compared to patients with either epilepsy without depression, or depression without epilepsy. 
These earlier studies then gave rise to more recent studies, which have utilized voxel-based morphometry (VBM) to assess brain structure and volume. Salgado [37] showed that patients with TLE and depression had more areas of grey matter volume loss compared with patients with TLE without depression, and normal controls. A study by Butler and colleagues [38] used a different imaging methodology using a quantitative measure of surface-based MRI analysis to assess cortical thickness. They found that in patients with TLE, more severe depressive symptoms were associated with thickening of the orbitofrontal cortex. In contrast, in healthy controls, increasing severity of depression was associated with thinning of the orbitofrontal cortex.

There have also been other novel methods of assessing hippocampal atrophy in patients with TLE such as MRI radial atrophy mapping (RAM), a 3-D surface modeling tool for measuring hippocampal atrophy. Using this method Finegersh [39] found that TLE patients with depression had atrophy in the superoanterior portion of the hippocampus contralateral to seizure focus compared to those without depression, supporting that contralateral hippocampal atrophy in TLE may be related to depression. Finally, there have also been studies using diffusion tensor imaging to assess white matter abnormalities in patients with TLE and depression. Kavanaugh [40] found that white matter abnormalities, particularly within the frontotemporolimbic regions, are associated with depressive symptomatology in patients with TLE.

\section{FUNCTIONAL NEUROIMAGING}

Functional neuroimaging studies revamped the importance of laterality and hemispheric asymmetries in epilepsy and depression. Doucet [41] demonstrated correlations between impaired functional connectivity and depression/ anxiety levels in both right and left TLE. However, in patients with right TLE, the higher the depression/ anxiety rating, the closer the functional connectivity values approached that of controls, whereas the reverse relationship was demonstrated for those with left TLE. The authors concluded that that right TLE has a more maladaptive impact on emotion-related networks (specific to the amygdala region), than left TLE. Functional changes in right TLE seem to involve also the ipsilateral hippocampal-cerebellar circuits [42].

A few authors showed that patients with epilepsy and depression present with a more complex network dysfunction, which may arise from disrupted fronto-limbic regions or the white matter tracts connecting them [43-46]. Patients with right TLE present with low contralateral uncinate fasciculus fractional anisotropy [44] which showed to be one of the strongest correlates of depressive symptoms. Right TLE and depression have been linked also to dysfunction of the default mode network [46,47]. Interestingly enough, a dysfunction in the default mode network was found also by the only study which focused on patients with genetic generalized epilepsies including juvenile myoclonic epilepsy, juvenile absence epilepsy and generalized tonic clonic seizures only [48].

\section{PHARMACO AND METABOLIC NEUROIMAGING}

\subsection{Cerebral Blood Flow}

Early studies used SPECT (Single-Photon Emission Computed Tomography) scanning to assess cerebral blood flow using the marker 99m Tc-HMPAO. Using this technique, Ring [49] found that patients with TLE and depression present with relatively greater cerebral activity in several regions including the left frontal, temporal, parietal and subcortical 
structures than those with epilepsy without depression. However, when compared to normal population data, these patients were not hyper-perfused despite demonstrating greater levels of perfusion and activity than non-depressed patients with epilepsy. Schmitz 1999 [50] also used 99m TC-HMPAO SPECT imaging but specifically compared patients with left versus right focal epilepsy in relation to measures of psychopathology and imaging perfusion findings. This study showed no differences between left and right epilepsy groups on measures of depression and obsessionality but did show different associations in relation to perfusion imaging. In patients with left sided epilepsy, higher scores on the Beck Depression Inventory were associated with lower contralateral temporal and bilateral frontal perfusion as well as higher occipital perfusion. In patients with right sided epilepsy, higher scores on the Leyton Obsessionality Inventory were associated with increased perfusion in ipsilateral temporal, thalamic and basal ganglia regions as well as bilateral frontal regions.

\subsection{Magnetic Resonance Spectroscopy}

Gilliam [51] used 1H magnetic resonance spectroscopy imaging (1H-MRSI) and examined the relationship between this and depressive symptoms as well as self-perceived social and vocational disability. This study found that the degree of hippocampal abnormalities as measured by $1 \mathrm{H}-\mathrm{MRSI}$ correlated with severity of the depression rating scores. A study by Peng [52] also used 1H-MRSI but mostly in patients with idiopathic generalized epilepsy or unclassified epilepsy. This study also showed that patients with epilepsy and depression have elevated ratio of glutamate/ glutamine to creatine in the right hippocampus, and that this is independently correlated with the Hamilton Depression Rating Scale score.

\subsection{FDG PET}

Studies utilizing FDG-PET (18F Fluorodeoxyglucose PET) to assess cerebral blood glucose metabolism have been conducted in patients with drug resistant TLE undergoing pre-surgical evaluation and requiring PET imaging as part of the pre-surgical work-up. One of the earliest studies by Bromfield [53] showed that patients with left TLE and depressive symptoms present with bilateral frontal cortex hypometabolism as compared to non-depressed patients, as well as normal controls. A further study by Victoroff [54] extended these findings and suggested that the degree of interictal temporal lobe hypometabolism as well as the laterality of ictal onset represent independent factors to the development of depression. However, Richardson et al. found no correlation between depressive symptoms and amygdala or hippocampus metabolism [34].

\subsection{Serotonin 5HT1A PET}

A few studies have demonstrated a relationship between the presence of comorbid depression in TLE and altered binding of several tracers including [18F]-FCWAY, [18F]-MPPF and [11C]-WAY. However, both negative and positive correlations between these 5-HT1A receptor binding potentials and depression in patients with TLE have been reported.

One of the earlier studies to examine 5HT1A receptor binding in patients with TLE and depression was that by Theodore [55]. This study showed an inverse correlation between corrected $[18 \mathrm{~F}]-F C W A Y$ ligand free fraction in the hippocampus ipsilateral to the seizure focus and depressive symptoms measured with the BDI. A similar but non-significant trend was found for the contralateral hippocampus. The presence of HS and the laterality did not have any effect on the BDI score. At the same time, Hasler and collaborators [56] replicated 
the same findings in patients with TLE and a lifetime diagnosis of major depression but they also showed that in patients with TLE and depression the low levels of 5-HT1A receptor binding extended to non-lesional limbic areas beyond the epileptic focus itself. Interestingly, when only patients with current (active) depression were included, the hippocampus was the only area that had significantly reduced receptor binding. Hasler's study also replicated the finding that the laterality and HS are associated with a lifetime diagnosis of depression, emphasizing the role for reduced 5-HT1A receptor binding in the mechanisms underlying depression in patients with TLE. A subsequent study by Theodore [57] also showed an inverse relationship between [18F]-FCWAY ipsilateral binding and BDI scores and a direct relationship between left hippocampal binding and memory function.

Studies with different tracers include [18F]-MPPF and [11C]-WAY. Lothe [58] found PET evidence of bilateral changes in patients with TLE and depression using [18F]-MPPF tracer. This study included patients with current (active) depression and drug-resistant TLE and HS confirmed on MRI. However, the author pointed out that depressive symptoms in patients with TLE are more likely to be due to lower extracellular concentration of serotonin, rather than the downregulation of receptors. They also showed that cognition symptoms of depression, psychomotor retardation and anhedonia positively correlated with [18F]-MPPF binding in the raphe nuclei and insula contralateral to the seizure focus whereas somatic symptoms were found to be positively correlated with binding in the ipsilateral hippocampal and parahippocampal regions as well as bilaterally in the cingulate gyrus and inferior dorsolateral frontal cortex.

Interestingly, a study by Assem-Hilger [59] using the [11C]-WAY tracer did not find a correlation between 5-HT1A receptor binding and depression scores, but their study included only 13 patients of which only 6 with depression.

\subsection{Serotonin transporter 5HTT PET}

Only two studies have evaluated the 5-HTT-serotonin transporter in patients with TLE and depression. Martinez [60] used the 5-HTT-transporter ligand 11C-3-amino-4-(2dimethylaminomethylphenylsulfanyl)-benzo-nitrile (11C-DASB) as well as the [18F]FCWAY ligand. This study pointed out that patients with TLE and depression have relatively reduced serotonin transporter activity ipsilateral to the seizure focus, compared to patients with TLE without depression or healthy controls. Conversely, Liik [61], using the radioligand 123I-ADAM in 7 patients with focal epilepsy and 5 patients with generalized epilepsy, showed no correlation between 123I-ADAM binding and depressive symptoms measured with the BDI or the EST-Q.

\section{DISCUSSION}

\subsection{Overview of studies and limitations}

Overall, almost all studies focused on TLE and a large majority of patients had HS. It is, therefore, unknown if these findings are specific to TLE or they apply to patients with GGE as well.

All studies are cross-sectional and none of them explored the so-called bidirectional relationship between epilepsy and depression following patients prospectively. Furthermore, the effect of treatment, both antidepressants and ASMs, is difficult to disentangle and not considered by almost all studies. The effect of antidepressants on brain structures in well-known [62]. The effect of ASMs on brain structures is less clear apart from 
the developmental effects [63]. Theodore [64] have specifically explored the effect of ASMs on 5-HT1A receptor binding in patients with TLE using PET and showed no effect of ASM on $[18 \mathrm{~F}]-F C W A Y$. However, further studies clarifying this point are needed.

Another limitation of these studies is the different approach in the assessment of depression and the heterogeneity of clinical instruments. Many studies explored current (active) symptoms of depression without structured clinical interview using standardized criteria to identify the underlying disorder. Depressive symptoms can occur in several conditions from major depression to persistent depressive disorder (formerly dysthymia) to bipolar disorder, psychotic depression etc. The lack of a categorical diagnosis using a structured clinical interview makes difficult to extend findings beyond the mood state. In this regard, no studies distinguished between first depressive episode and recurrent depression and no studies have considered the number of previous depressive episodes as well as the age of onset of depression. All these factors, as discussed below, are important clinical correlate of neuroimaging findings in people with mood disorders.

Finally, authors did not compare their findings with the large literature on neuroimaging of depression outside epilepsy to try to dissect out the relative contribution of one condition as compared to the other.

\subsection{Differences between major depression and depression in epilepsy}

During recent years, most data on neuroimaging of major depressive disorder (MDD) came from the MDD Working Group of the Enhancing Neuroimaging Genetics through MetaAnalysis (ENIGMA) consortium based on Worldwide Data Sharing from 14 different countries including brain scans from around $>5,000$ patients with major depression and $>9,000$ controls [65]. Data from the ENIGMA consortium is providing high quality and highly reliable data on neuroimaging on depression outside epilepsy. Looking at the findings in epilepsy a few differences are noticeable despite the already mentioned limitations of the epilepsy literature.

Regarding structural neuroimaging, hippocampal volume loss is a well-established finding in MDD outside epilepsy [66,67] and, for a long time, it has been considered a very important link between epilepsy and depression. However, data from patients with MDD have pointed out that hippocampal atrophy is a reversible process with antidepressant treatments $[68,69]$ while the same phenomenon does not seem to happen in epilepsy. Furthermore, hippocampal atrophy in MDD seems to be associated with an early onset of the depression (adolescence or childhood) and correlates with the number of depressive episodes and more chronic and persistent symptoms [70]. Interestingly enough, hippocampal volume loss in MDD seems to largely predate the onset of depression as a clinical syndrome [71]. This point can be of potential interest regarding the so-called bidirectional relationship with epilepsy, but no studies have investigated this point.

Finally, the hippocampal areas involved seem to be different between epilepsy and MDD. In fact, in MDD CA2 and CA3 are usually affected with relative preservation of other areas apart from the subiculum [71] while HS involves especially CA1 and CA4 [72]. All studies in patients with epilepsy and depression are concordant in hippocampal volume loss as an hallmark but it is still unknown whether this is more the "epilepsy-type" or "MDD-type " of atrophy in terms of hippocampal structures involved and whether there is a degree of potential reversibility with antidepressant treatment. 
Another difference between studies in MDD and depression in epilepsy is the involvement of cortical and subcortical structures. In MDD, it is well established that adult onset MDD is mainly characterized by cortical abnormalities with relative preservation of subcortical structures apart from the hippocampi. Smaller amygdalae are, for example, reported in early onset (childhood, adolescence) depression [71]. Conversely, studies of depression in epilepsy report a number of changes in subcortical structures, especially the amygdala, despite being an adult onset depression.

On the other hand, pattern of cortical changes seem to be similar in both MDD and depression in epilepsy focusing on cortico-limbic thickness alterations including the anterior cingulate and prefrontal cortex as well as medial orbitofrontal cortex which seems to correlate with hippocampal volumes [71]. Another concordant point between studies of depression in epilepsy and studies in MDD is the lack of a laterality effect. Though not specifically investigated in MDD, hemispheric asymmetries seem to play a marginal role [73]. In the same way, the involvement of one specific hemisphere by the epileptic dysfunction does not seem to play a relevant role in terms of pathophysiology. Early PET [53,54] and SPECT studies [50] seem to suggest that left TLE was more likely to be associated with frontal lobe dysfunction and depression, a phenomenon also known as "hypofrontality" [50]. However, all studies taking together do not suggest an increased association between left TLE as compared to right TLE. A dysfunction in cortico-limbic networks involving the frontal lobes is in fact reported also in MDD.

Data on the involvement of the default mode network see to be different as MDD seems to be associated with hyperconnectivity [74] while TLE with or without depression is associated with hypoconnectivity [75]. Implications of these differences need to be investigated.

Data coming from pharmaco-neuroimaging are quite interesting. Reduced 5HT1A binding was shown in both MDD and depression in epilepsy. Reduced 5HT1A seems to reflect hippocampal network inhibition mediated by raphe nuclei hypofunction [76]. However, while studies in MDD point towards reduced receptor density than low serotonin levels, studies of depression in epilepsy point towards reduced serotonin levels and serotonin availability. Low serotonin levels have been reported in several animal models of epilepsy and it has been claimed as one of the main mechanisms behind the double relationship between epilepsy and depression [6]. Whether chronically low levels may determine over time network changes responsible for both conditions need to be further clarified.

\subsection{Post-surgical depression}

Depression following epilepsy surgery deserves a separate discussion. Some neuroimaging studies specifically investigated post-surgical depression. Paparrigopoulous [77] showed that severity of depressive symptomatology in operated patients correlated with the extent of hippocampal and amygdala resection particularly in left-side resections. Wrench [78] explored whether pre-operative MRI hippocampal volumes were associated with depression following epilepsy surgery and demonstrated different findings for those undergoing mesial temporal lobe resections as compared to non-mesial temporal lobe resections. In those undergoing mesial temporal lobe resections, post-operative depression was associated with smaller hippocampal volumes contralateral to the resection and this was also seen for those patients who developed de novo depression. However, for patients with non-mesial temporal lobe epilepsy hippocampal volumes were not related to post-operative depression. Pope [79] specifically looked at patients who developed de novo depression post-operatively using VBM assessment. Patients with left-sided HS who developed de novo depression within 4- 
years post-operatively were found to have reduced preoperative bilateral grey matter in orbitofrontal cortices, ipsilateral cingulate gyrus, and thalamus. This is also supported by pharmaco-MRI studies looking at patients undergoing epilepsy surgery. Functional MRI studies in patients with TLE undergoing anterior temporal lobe resections have found specific patterns of activation in patients with right-sided HS but not left. Bonelli [80], using a memory encoding functional MRI paradigm, showed that patients with right TLE, amygdala activation was significantly related to pre-operative levels of anxiety and depression. Activation of the right amygdala pre-operatively was also predictive of post-operative changes of anxiety and depression, but these findings were not demonstrated for patients with left TLE. Salzberg [81] showed that patients with TLE and a history of depression preoperatively had focal hypometabolism in the left orbitofrontal cortex compared to those without a preoperative history of depression and these patients also developed depression post-operatively.

\section{CONCLUSIONS AND FUTURE DIRECTIONS}

Most neuroimaging studies of depression in epilepsy focused on structural abnormalities in patients with TLE. These studies have shown more widespread subcortical abnormalities as compared to studies in MDD. The pattern of hippocampal abnormalities seems to be different in MDD as compared to HS suggesting that HS per se may not be relevant. Functional neuroimaging studies have shown network dysfunctions like those described in MDD and involving primarily the fronto-limbic circuits. These studies have also often showed a correlation between depressive symptoms and a dysfunction in temporolimbic structures contralateral to the epileptogenic zone especially in patients with post-surgical depression. However, further studies are needed to clarify this point.

Whether differences are clinically relevant and subtend phenomenological or clinical variations is difficult to tell but they may strongly support the notion that depression in epilepsy, at least in TLE, may be phenomenologically different from depression outside epilepsy. Studies aimed at clarifying this point are urgently needed.

Future studies will also need to focus on other epilepsy syndromes, as data on GGE or other syndromes are, at present, non-existent. These data will clarify whether brain changes seen in patients with TLE and depression are more similar to MDD or those reported in TLE, providing further insights on the role of temporal structures on mood dysfunction in epilepsy. Finally, studies should also focus on new onset epilepsies investigating prospectively brain changes in order to clarify neurobiological mechanisms behind the bi-directional relationship between epilepsy and depression.

\section{ACKNOWLEDGMENT}

This work did not receive any specific funding.

\section{CONFLICTS OF INTEREST}

SE reports no conflict of interests. MM reports personal fees from UCB, Eisai, Bial, Elsevier, outside the submitted work; in addition, he also has intellectual property rights with Springer and Elsevier. 


\section{REFERENCES}

[1] Mula M. Depression in epilepsy: Current Opinion in Neurology 2017;30:180-6. https://doi.org/10.1097/WCO.0000000000000431.

[2] Fiest KM, Dykeman J, Patten SB, Wiebe S, Kaplan GG, Maxwell CJ, et al. Depression in epilepsy: A systematic review and meta-analysis. Neurology 2013;80:590-9. https://doi.org/10.1212/WNL.0b013e31827b1ae0.

[3] Temkin O. The falling sickness: a history of epilepsy from the Greeks to the beginnings of modern neurology. 2. ed., rev. Baltimore: Hopkins Univ. Press; 1994.

[4] Adelow C, Andersson T, Ahlbom A, Tomson T. Hospitalization for psychiatric disorders before and after onset of unprovoked seizures/epilepsy. Neurology 2012;78:396-401. https://doi.org/10.1212/WNL.0b013e318245f461.

[5] Hesdorffer DC, Ishihara L, Mynepalli L, Webb DJ, Weil J, Hauser WA. Epilepsy, suicidality, and psychiatric disorders: A bidirectional association. Ann Neurol 2012;72:184-91. https://doi.org/10.1002/ana.23601.

[6] Kanner AM. Can neurobiological pathogenic mechanisms of depression facilitate the development of seizure disorders? The Lancet Neurology 2012;11:1093-102. https://doi.org/10.1016/S1474-4422(12)70201-6.

[7] Mazarati A, Siddarth P, Baldwin RA, Shin D, Caplan R, Sankar R. Depression after status epilepticus: behavioural and biochemical deficits and effects of fluoxetine. Brain 2008;131:2071-83. https://doi.org/10.1093/brain/awn117.

[8] Jobe PC. Common pathogenic mechanisms between depression and epilepsy: an experimental perspective. Epilepsy \& Behavior 2003;4:14-24. https://doi.org/10.1016/j.yebeh.2003.08.020.

[9] Rajkowska G, Miguel-Hidalgo JJ, Wei J, Dilley G, Pittman SD, Meltzer HY, et al. Morphometric evidence for neuronal and glial prefrontal cell pathology in major depression $* *$ See accompanying Editorial, in this issue. Biological Psychiatry 1999;45:1085-98. https://doi.org/10.1016/S0006-3223(99)00041-4.

[10] Kumar G, Couper A, O’Brien TJ, Salzberg MR, Jones NC, Rees SM, et al. The acceleration of amygdala kindling epileptogenesis by chronic low-dose corticosterone involves both mineralocorticoid and glucocorticoid receptors.

Psychoneuroendocrinology 2007;32:834-42. https://doi.org/10.1016/j.psyneuen.2007.05.011.

[11] Boylan LS, Flint LA, Labovitz DL, Jackson SC, Starner K, Devinsky O. Depression but not seizure frequency predicts quality of life in treatment-resistant epilepsy. Neurology 2004;62:258-61. https://doi.org/10.1212/01.WNL.0000103282.62353.85.

[12] Hitiris N, Mohanraj R, Norrie J, Sills GJ, Brodie MJ. Predictors of pharmacoresistant epilepsy. Epilepsy Research 2007;75:192-6. https://doi.org/10.1016/j.eplepsyres.2007.06.003.

[13] Nogueira MH, Yasuda CL, Coan AC, Kanner AM, Cendes F. Concurrent mood and anxiety disorders are associated with pharmacoresistant seizures in patients with MTLE. Epilepsia 2017;58:1268-76. https://doi.org/10.1111/epi.13781.

[14] Cramer JA, Blum D, Reed M, Fanning K, Epilepsy Impact Project Group. The Influence of Comorbid Depression on Seizure Severity. Epilepsia 2003;44:1578-84. https://doi.org/10.1111/j.0013-9580.2003.28403.x.

[15] Mula M, von Oertzen TJ, Cock HR, Lozsadi DA, Agrawal N. Clinical correlates of memory complaints during AED treatment. Acta Neurol Scand 2016;134:368-73. https://doi.org/10.1111/ane.12553. 
[16] Gur-Ozmen S, Mula M, Agrawal N, Cock HR, Lozsadi D, von Oertzen TJ. The effect of depression and side effects of antiepileptic drugs on injuries in patients with epilepsy. Eur J Neurol 2017;24:1135-9. https://doi.org/10.1111/ene.13346.

[17] Kanner AM, Byrne R, Chicharro A, Wuu J, Frey M. A lifetime psychiatric history predicts a worse seizure outcome following temporal lobectomy. Neurology 2009;72:793-9. https://doi.org/10.1212/01.wnl.0000343850.85763.9c.

[18] Fazel S, Wolf A, Långström N, Newton CR, Lichtenstein P. Premature mortality in epilepsy and the role of psychiatric comorbidity: a total population study. The Lancet 2013;382:1646-54. https://doi.org/10.1016/S0140-6736(13)60899-5.

[19] Kanner AM, Schachter SC, Barry JJ, Hersdorffer DC, Mula M, Trimble M, et al. Depression and epilepsy: Epidemiologic and neurobiologic perspectives that may explain their high comorbid occurrence. Epilepsy \& Behavior 2012;24:156-68. https://doi.org/10.1016/j.yebeh.2012.01.007.

[20] Sheline YI, Gado MH, Kraemer HC. Untreated Depression and Hippocampal Volume Loss. AJP 2003;160:1516-8. https://doi.org/10.1176/appi.ajp.160.8.1516.

[21] Cotter D. Reduced Neuronal Size and Glial Cell Density in Area 9 of the Dorsolateral Prefrontal Cortex in Subjects with Major Depressive Disorder. Cerebral Cortex 2002;12:386-94. https://doi.org/10.1093/cercor/12.4.386.

[22] Cotter D, Mackay D, Landau S, Kerwin R, Everall I. Reduced Glial Cell Density and Neuronal Size in the Anterior Cingulate Cortex in Major Depressive Disorder. Arch Gen Psychiatry 2001;58:545. https://doi.org/10.1001/archpsyc.58.6.545.

[23] Quiske A, Helmstaedter C, Lux S, Elger CE. Depression in patients with temporal lobe epilepsy is related to mesial temporal sclerosis. Epilepsy Research 2000;39:121-5. https://doi.org/10.1016/S0920-1211(99)00117-5.

[24] Nees H, Moriarty J, Kitchen ND, Trimble MR. Psychosocial and Neurobehavioral Factors Related to Surgical Treatment for Partial Epilepsy: A Multivariate Analysis. Epilepsy \& Behavior 2001;2:135-9. https://doi.org/10.1006/ebeh.2001.0161.

[25] Baxendale SA, Thompson PJ, Duncan JS. Epilepsy \& depression: The effects of comorbidity on hippocampal volume-A pilot study. Seizure 2005;14:435-8. https://doi.org/10.1016/j.seizure.2005.07.003.

[26] Sanchez-Gistau V, Sugranyes G, Baillés E, Carreño M, Donaire A, Bargalló N, et al. Is major depressive disorder specifically associated with mesial temporal sclerosis?: Mesial Temporal Sclerosis. Epilepsia 2012;53:386-92. https://doi.org/10.1111/j.15281167.2011.03373.x.

[27] Devinsky O, Barr WB, Vickrey BG, Berg AT, Bazil CW, Pacia SV, et al. Changes in depression and anxiety after resective surgery for epilepsy. Neurology 2005;65:1744-9. https://doi.org/10.1212/01.wnl.0000187114.71524.c3.

[28] Briellmann RS, Hopwood MJ, Jackson GD. Major depression in temporal lobe epilepsy with hippocampal sclerosis: clinical and imaging correlates. Journal of Neurology, Neurosurgery \&amp; Psychiatry 2007;78:1226-30. https://doi.org/10.1136/jnnp.2006.104521.

[29] Gonçalves EB, de Oliveira Cardoso TAM, Yasuda CL, Cendes F. Depressive disorders in patients with pharmaco-resistant mesial temporal lobe epilepsy. J Int Med Res 2018;46:752-60. https://doi.org/10.1177/0300060517717825.

[30] Adams SJ, O’Brien TJ, Lloyd J, Kilpatrick CJ, Salzberg MR, Velakoulis D. Neuropsychiatric morbidity in focal epilepsy. Br J Psychiatry 2008;192:464-9. https://doi.org/10.1192/bjp.bp.107.046664.

[31] Rayner G, Tailby C, Jackson G, Wilson S. Looking beyond lesions for causes of neuropsychological impairment in epilepsy. Neurology 2019;92:e680-9. https://doi.org/10.1212/WNL.0000000000006905. 
[32] Shamim S, Hasler G, Liew C, Sato S, Theodore WH. Temporal lobe epilepsy, depression, and hippocampal volume. Epilepsia 2009;50:1067-71. https://doi.org/10.1111/j.1528-1167.2008.01883.x.

[33] Hecimovic H, Santos J, Price JL, Sheline YI, Mintun MA, Snyder AZ, et al. Severe hippocampal atrophy is not associated with depression in temporal lobe epilepsy. Epilepsy \& Behavior 2014;34:9-14. https://doi.org/10.1016/j.yebeh.2014.02.034.

[34] Richardson EJ, Griffith HR, Martin RC, Paige AL, Stewart CC, Jones J, et al. Structural and functional neuroimaging correlates of depression in temporal lobe epilepsy. Epilepsy \& Behavior 2007;10:242-9. https://doi.org/10.1016/j.yebeh.2006.11.013.

[35] Tebartz van Elst L, Woermann FG, Lemieux L, Trimble MR. Amygdala enlargement in dysthymia - a volumetric study of patients with temporal lobe epilepsy. Biological Psychiatry 1999;46:1614-23. https://doi.org/10.1016/S0006-3223(99)00212-7.

[36] Elst LT van, Groffmann M, Ebert D, Schulze-Bonhage A. Amygdala volume loss in patients with dysphoric disorder of epilepsy. Epilepsy \& Behavior 2009;16:105-12. https://doi.org/10.1016/j.yebeh.2009.06.009.

[37] Salgado PCB, Yasuda CL, Cendes F. Neuroimaging changes in mesial temporal lobe epilepsy are magnified in the presence of depression. Epilepsy \& Behavior 2010;19:422-7. https://doi.org/10.1016/j.yebeh.2010.08.012.

[38] Butler T, Blackmon K, McDonald CR, Carlson C, Barr WB, Devinsky O, et al. Cortical thickness abnormalities associated with depressive symptoms in temporal lobe epilepsy. Epilepsy \& Behavior 2012;23:64-7. https://doi.org/10.1016/j.yebeh.2011.10.001.

[39] Finegersh A, Avedissian C, Shamim S, Dustin I, Thompson PM, Theodore WH. Bilateral hippocampal atrophy in temporal lobe epilepsy: Effect of depressive symptoms and febrile seizures: 3D Surface Mapping of Epilepsy Comorbidities. Epilepsia 2011;52:689-97. https://doi.org/10.1111/j.1528-1167.2010.02928.x.

[40] Kavanaugh B, Correia S, Jones J, Blum A, LaFrance WC, Davis JD. White matter integrity correlates with depressive symptomatology in temporal lobe epilepsy. Epilepsy \& Behavior 2017;77:99-105. https://doi.org/10.1016/j.yebeh.2017.07.035.

[41] Doucet GE, Skidmore C, Sharan AD, Sperling MR, Tracy JI. Functional connectivity abnormalities vary by amygdala subdivision and are associated with psychiatric symptoms in unilateral temporal epilepsy. Brain and Cognition 2013;83:171-82. https://doi.org/10.1016/j.bandc.2013.08.001.

[42] Peng W, Mao L, Yin D, Sun W, Wang H, Zhang Q, et al. Functional network changes in the hippocampus contribute to depressive symptoms in epilepsy. Seizure 2018;60:1622. https://doi.org/10.1016/j.seizure.2018.06.001.

[43] Chen S, Wu X, Lui S, Wu Q, Yao Z, Li Q, et al. Resting-state fMRI study of treatmentnaïve temporal lobe epilepsy patients with depressive symptoms. NeuroImage 2012;60:299-304. https://doi.org/10.1016/j.neuroimage.2011.11.092.

[44] Kemmotsu N, Kucukboyaci NE, Leyden KM, Cheng CE, Girard HM, Iragui VJ, et al. Frontolimbic brain networks predict depressive symptoms in temporal lobe epilepsy. Epilepsy Research 2014;108:1554-63. https://doi.org/10.1016/j.eplepsyres.2014.08.018.

[45] Kemmotsu N, Kucukboyaci NE, Cheng CE, Girard HM, Tecoma ES, Iragui VJ, et al. Alterations in functional connectivity between the hippocampus and prefrontal cortex as a correlate of depressive symptoms in temporal lobe epilepsy. Epilepsy \& Behavior 2013;29:552-9. https://doi.org/10.1016/j.yebeh.2013.09.039.

[46] Zhu X, He Z, Luo C, Qiu X, He S, Peng A, et al. Altered spontaneous brain activity in MRI-negative refractory temporal lobe epilepsy patients with major depressive disorder: A resting-state fMRI study. Journal of the Neurological Sciences 2018;386:29-35. https://doi.org/10.1016/j.jns.2018.01.010. 
[47] Stretton J, Pope RA, Winston GP, Sidhu MK, Symms M, Duncan JS, et al. Temporal lobe epilepsy and affective disorders: the role of the subgenual anterior cingulate cortex. Journal of Neurology, Neurosurgery \& Psychiatry 2015;86:144-51. https://doi.org/10.1136/jnnp-2013-306966.

[48] Garcia D dos S, Polydoro MS, Alvim MKM, Ishikawa A, Moreira JCV, Nogueira MH, et al. Anxiety and depression symptoms disrupt resting state connectivity in patients with genetic generalized epilepsies. Epilepsia 2019;60:679-88. https://doi.org/10.1111/epi.14687.

[49] Ring HA, Acton PD, Scull D, Costa DC, Gacinovik S, Trimble MR. Patterns of brain activity in patients with epilepsy and depression. Seizure 1999;8:390-7. https://doi.org/10.1053/seiz.1999.0320.

[50] Schmitz EB, Moriarty J, Costa DC, Ring HA, Ell PJ, Trimble MR. Psychiatric profiles and patterns of cerebral blood flow in focal epilepsy: interactions between depression, obsessionality, and perfusion related to the laterality of the epilepsy. Journal of Neurology, Neurosurgery \& Psychiatry 1997;62:458-63. https://doi.org/10.1136/jnnp.62.5.458.

[51] Gilliam FG, Maton BM, Martin RC, Sawrie SM, Faught RE, Hugg JW, et al. Hippocampal 1H-MRSI correlates with severity of depression symptoms in temporal lobe epilepsy. Neurology 2007;68:364-8. https://doi.org/10.1212/01.wnl.0000252813.86812.81.

[52] Peng W-F, Ding J, Mao L-Y, Li X, Liang L, Chen C-Z, et al. Increased ratio of glutamate/glutamine to creatine in the right hippocampus contributes to depressive symptoms in patients with epilepsy. Epilepsy \& Behavior 2013;29:144-9. https://doi.org/10.1016/j.yebeh.2013.07.004.

[53] Bromfield EB, Altshuler L, Leiderman DB, Balish M, Ketter TA, Devinsky O, et al. Cerebral Metabolism and Depression in Patients With Complex Partial Seizures. Archives of Neurology 1992;49:617-23. https://doi.org/10.1001/archneur.1992.00530300049010.

[54] Victoroff JI, Benson DF, Grafton ST, Engel J, Mazziotta JC. Depression in Complex Partial Seizures Electroencephalography and Cerebral Metabolic Correlates. Archives of Neurology 1994;51:155-63. https://doi.org/10.1001/archneur.1994.00540140061016.

[55] Theodore WH, Hasler G, Giovacchini G, Kelley K, Reeves-Tyer P, Herscovitch P, et al. Reduced Hippocampal 5HT1A PET Receptor Binding and Depression in Temporal Lobe Epilepsy: 5HT1A PET AND DEPRESSION IN EPILEPSY. Epilepsia 2007;48:1526-30. https://doi.org/10.1111/j.1528-1167.2007.01089.x.

[56] Hasler G, Bonwetsch R, Giovacchini G, Toczek MT, Bagic A, Luckenbaugh DA, et al. 5-HT1A Receptor Binding in Temporal Lobe Epilepsy Patients With and Without Major Depression. Biological Psychiatry 2007;62:1258-64. https://doi.org/10.1016/j.biopsych.2007.02.015.

[57] Theodore WH, Wiggs EA, Martinez AR, Dustin IH, Khan OI, Appel S, et al. Serotonin 1A receptors, depression, and memory in temporal lobe epilepsy: 5HT1A Receptors, Depression, Memory, and TLE. Epilepsia 2012;53:129-33. https://doi.org/10.1111/j.1528-1167.2011.03309.x.

[58] Lothe A, Didelot A, Hammers A, Costes N, Saoud M, Gilliam F, et al. Comorbidity between temporal lobe epilepsy and depression: a [18 F]MPPF PET study. Brain 2008;131:2765-82. https://doi.org/10.1093/brain/awn194.

[59] Assem-Hilger E, Lanzenberger R, Savli M, Wadsak W, Mitterhauser M, Mien L-K, et al. Central serotonin 1A receptor binding in temporal lobe epilepsy: A [carbonyl11C]WAY-100635 PET study. Epilepsy \& Behavior 2010;19:467-73. https://doi.org/10.1016/j.yebeh.2010.07.030. 
[60] Martinez A, Finegersh A, Cannon DM, Dustin I, Nugent A, Herscovitch P, et al. The 5HT1A receptor and 5-HT transporter in temporal lobe epilepsy. Neurology 2013;80:1465-71. https://doi.org/10.1212/WNL.0b013e31828cf809.

[61] Liik M, Paris M, Vahter L, Gross-Paju K, Haldre S. 123I-ADAM SPET imaging of serotonin transporter in patients with epilepsy and comorbid depression. BMC Neurol 2013;13:204. https://doi.org/10.1186/1471-2377-13-204.

[62] Dusi N, Barlati S, Vita A, Brambilla P. Brain Structural Effects of Antidepressant Treatment in Major Depression. CN 2015;13:458-65. https://doi.org/10.2174/1570159X1304150831121909.

[63] Meador KJ, Loring DW. Developmental effects of antiepileptic drugs and the need for improved regulations. Neurology 2016;86:297-306. https://doi.org/10.1212/WNL.0000000000002119.

[64] Theodore WH, Giovacchini G, Bonwetsch R, Bagic A, Reeves-Tyer P, Herscovitch P, et al. The Effect of Antiepileptic Drugs on 5-HT1A-Receptor Binding Measured by Positron Emission Tomography. Epilepsia 2006;47:499-503. https://doi.org/10.1111/j.1528-1167.2006.00458.x.

[65] the Alzheimer's Disease Neuroimaging Initiative, EPIGEN Consortium, IMAGEN Consortium, Saguenay Youth Study (SYS) Group, Thompson PM, Stein JL, Medland SE, Hibar DP, Vasquez AA, et al. The ENIGMA Consortium: large-scale collaborative analyses of neuroimaging and genetic data. Brain Imaging and Behavior 2014;8:15382. https://doi.org/10.1007/s11682-013-9269-5.

[66] Arnone D, McIntosh AM, Ebmeier KP, Munafò MR, Anderson IM. Magnetic resonance imaging studies in unipolar depression: Systematic review and meta-regression analyses. European Neuropsychopharmacology 2012;22:1-16. https://doi.org/10.1016/j.euroneuro.2011.05.003.

[67] Cole J, Costafreda SG, McGuffin P, Fu CHY. Hippocampal atrophy in first episode depression: A meta-analysis of magnetic resonance imaging studies. Journal of Affective Disorders 2011;134:483-7. https://doi.org/10.1016/j.jad.2011.05.057.

[68] Arnone D, McKie S, Elliott R, Juhasz G, Thomas EJ, Downey D, et al. State-dependent changes in hippocampal grey matter in depression. Mol Psychiatry 2013;18:1265-72. https://doi.org/10.1038/mp.2012.150.

[69] Oltedal L, Narr KL, Abbott C, Anand A, Argyelan M, Bartsch H, et al. Volume of the Human Hippocampus and Clinical Response Following Electroconvulsive Therapy. Biological Psychiatry 2018;84:574-81. https://doi.org/10.1016/j.biopsych.2018.05.017.

[70] Elbejjani M, Fuhrer R, Abrahamowicz M, Mazoyer B, Crivello F, Tzourio C, et al. Depression, depressive symptoms, and rate of hippocampal atrophy in a longitudinal cohort of older men and women. Psychol Med 2015;45:1931-44. https://doi.org/10.1017/S0033291714003055.

[71] Schmaal L, Pozzi E, C. Ho T, van Velzen LS, Veer IM, Opel N, et al. ENIGMA MDD: seven years of global neuroimaging studies of major depression through worldwide data sharing. Transl Psychiatry 2020;10:172. https://doi.org/10.1038/s41398-020-0842-6.

[72] Blümcke I, Thom M, Aronica E, Armstrong DD, Bartolomei F, Bernasconi A, et al. International consensus classification of hippocampal sclerosis in temporal lobe epilepsy: A Task Force report from the ILAE Commission on Diagnostic Methods. Epilepsia 2013;54:1315-29. https://doi.org/10.1111/epi.12220.

[73] for the ENIGMA-Major Depressive Disorder Working Group, Schmaal L, Hibar DP, Sämann PG, Hall GB, Baune BT, et al. Cortical abnormalities in adults and adolescents with major depression based on brain scans from 20 cohorts worldwide in the ENIGMA Major Depressive Disorder Working Group. Mol Psychiatry 2017;22:900-9. https://doi.org/10.1038/mp.2016.60. 
[74] Kaiser RH, Andrews-Hanna JR, Wager TD, Pizzagalli DA. Large-Scale Network Dysfunction in Major Depressive Disorder: A Meta-analysis of Resting-State Functional Connectivity. JAMA Psychiatry 2015;72:603. https://doi.org/10.1001/jamapsychiatry.2015.0071.

[75] Liao W, Zhang Z, Pan Z, Mantini D, Ding J, Duan X, et al. Default mode network abnormalities in mesial temporal lobe epilepsy: A study combining fMRI and DTI. Hum Brain Mapp 2011;32:883-95. https://doi.org/10.1002/hbm.21076.

[76] Schneck N, Tu T, Falcone HR, Miller JM, Zanderigo F, Sublette ME, et al. Large-scale network dynamics in neural response to emotionally negative stimuli linked to serotonin 1A binding in major depressive disorder. Mol Psychiatry 2020. https://doi.org/10.1038/s41380-020-0733-5.

[77] Paparrigopoulos T, Ferentinos P, Brierley B, Shaw P, David AS. Relationship between post-operative depression/anxiety and hippocampal/amygdala volumes in temporal lobectomy for epilepsy. Epilepsy Research 2008;81:30-5. https://doi.org/10.1016/j.eplepsyres.2008.04.011.

[78] Wrench JM, Wilson SJ, Bladin PF, Reutens DC. Hippocampal volume and depression: insights from epilepsy surgery. Journal of Neurology, Neurosurgery \& Psychiatry 2009;80:539-44. https://doi.org/10.1136/jnnp.2008.152165.

[79] Pope RA, Centeno M, Flügel D, Symms MR, Koepp M, Thompson PJ, et al. Neural correlates of de novo depression following left temporal lobe epilepsy surgery: A voxel based morphometry study of pre-surgical structural MRI. Epilepsy Research 2014;108:517-25. https://doi.org/10.1016/j.eplepsyres.2013.12.003.

[80] Bonelli SB, Powell R, Yogarajah M, Thompson PJ, Symms MR, Koepp MJ, et al. Preoperative amygdala fMRI in temporal lobe epilepsy: Imaging Amygdala Function in TLE. Epilepsia 2009;50:217-27. https://doi.org/10.1111/j.1528-1167.2008.01739.x.

[81] Salzberg M, Taher T, Davie M, Carne R, Hicks RJ, Cook M, et al. Depression in Temporal Lobe Epilepsy Surgery Patients: An FDG-PET Study: TLE SURGERY, DEPRESSION, AND FDG-PET. Epilepsia 2006;47:2125-30.

https://doi.org/10.1111/j.1528-1167.2006.00860.x. 
Figure 1. PRISMA flow diagram neuroimaging studies of depression in epilepsy.

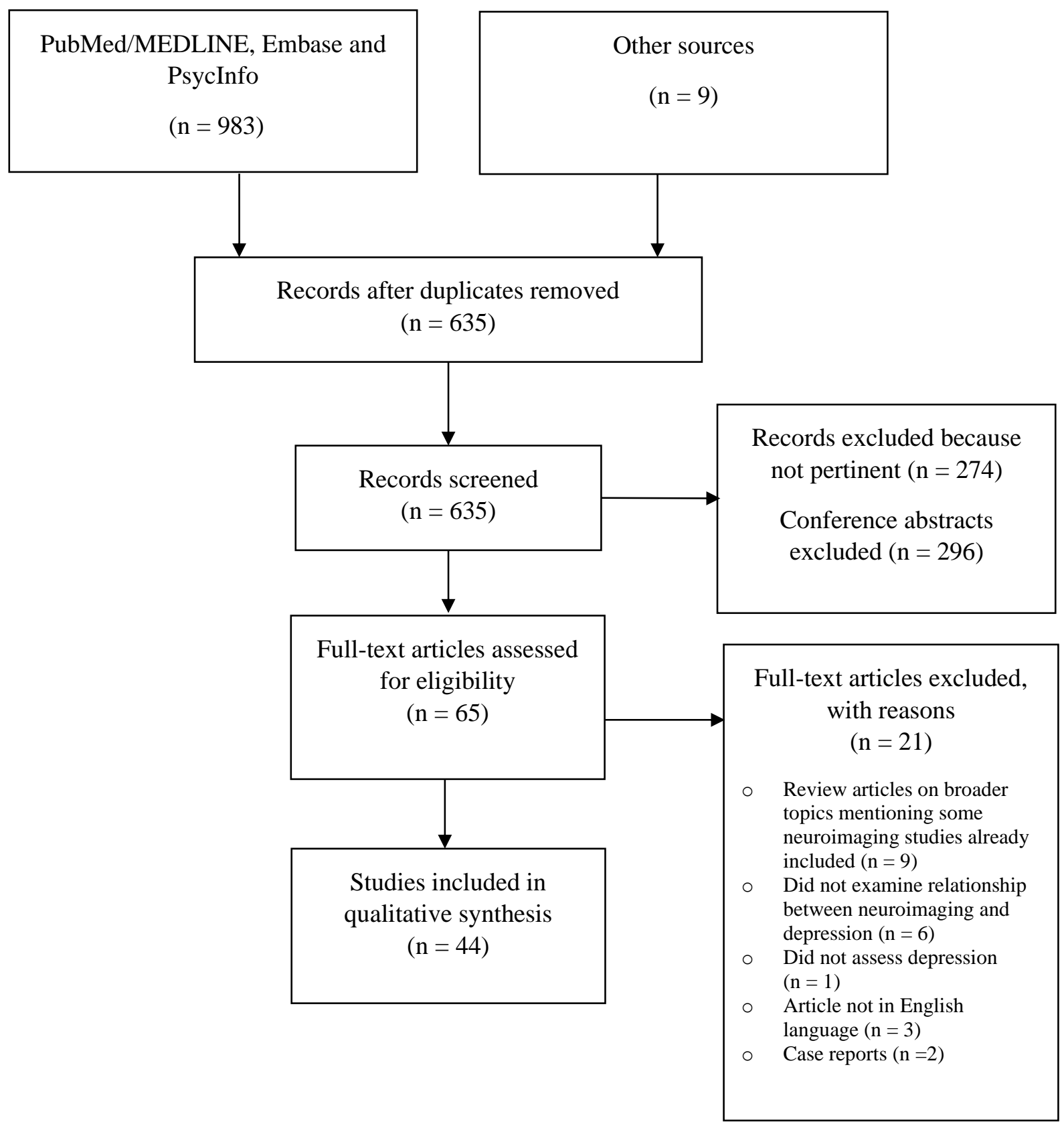


Table 1. Neuroimaging studies of depression in epilepsy. Qualitative synthesis of included studies.

\begin{tabular}{|c|c|c|c|c|c|c|c|c|}
\hline \multicolumn{9}{|c|}{ STRUCTURAL NEUROIMAGING } \\
\hline Reference & $\begin{array}{c}\text { No of } \\
\text { patients }\end{array}$ & Country & Epilepsy type & $\begin{array}{c}\text { Seizure } \\
\text { frequency }\end{array}$ & $\begin{array}{l}\text { Imaging } \\
\text { Technique }\end{array}$ & $\begin{array}{l}\text { Depression } \\
\text { assessment }\end{array}$ & $\begin{array}{l}\text { Antidepres } \\
\text { sants }\end{array}$ & Depression correlates \\
\hline $\begin{array}{l}\text { Van Elst et } \\
\text { al } 1999 \text { [35] }\end{array}$ & 70 & UK & $\begin{array}{c}50 \text { mTLE vs. } 20 \\
\text { controls }\end{array}$ & No SF & $\begin{array}{l}\text { Structural } \\
\text { MRI - } \\
\text { Amygdala } \\
\text { Volumetry }\end{array}$ & $\begin{array}{l}\text { Psychiatric } \\
\text { assessment } \\
\text { through } \\
\text { DSM-IV } \\
\text { BDI }\end{array}$ & None & $\begin{array}{l}\text { Enlarged bilateral } \\
\text { amygdala volumes } \\
\text { L amygdala volumes } \\
\text { correlated with BDI } \\
\text { scores }\end{array}$ \\
\hline $\begin{array}{l}\text { Quiske et al } \\
2000[23]\end{array}$ & 60 & Germany & $\begin{array}{l}\text { mTLE with HS } \\
\text { vs. ITLE }\end{array}$ & No SF & $\begin{array}{c}\text { Structural } \\
\text { MRI - T1W, } \\
\text { T2W, Coronal } \\
\text { FLAIR, } \\
\text { Hippocampal } \\
\text { Volumetry }\end{array}$ & BDI & Not known & $\begin{array}{l}\text { HS independent on } \\
\text { lateralization }\end{array}$ \\
\hline $\begin{array}{l}\text { Nees et al } \\
2001[24]\end{array}$ & 50 & UK & $\begin{array}{l}\text { mTLE (lesional } \\
\text { and non- } \\
\text { lesional) }\end{array}$ & $\begin{array}{c}22 \mathrm{SF} ; \\
21 \\
\text { persistent } \\
\text { auras; } \\
6 \text { ongoing } \\
\text { BTC } \\
\text { seizures }\end{array}$ & $\begin{array}{c}\text { Structural } \\
\text { MRI - T1W, } \\
\text { T2W, Coronal } \\
\text { FLAIR, } \\
\text { Hippocampal } \\
\text { Volumetry, } \\
\text { Hippocampal } \\
\text { T2 maps } \\
\end{array}$ & BDI & Not known & RHS \\
\hline $\begin{array}{c}\text { Baxendale } \\
\text { et al 2005 } \\
{[25]}\end{array}$ & 87 & UK & mTLE with HS & Not known & $\begin{array}{c}\text { Structural } \\
\text { MRI - T1W, } \\
\text { T2W, Coronal } \\
\text { FLAIR, } \\
\text { Hippocampal } \\
\text { Volumetry } \\
\end{array}$ & HADS & Not known & LHS \\
\hline $\begin{array}{l}\text { Devinsky et } \\
\text { al } 2005 \text { [27] }\end{array}$ & 360 & $\begin{array}{c}\text { USA } \\
\text { Multicent } \\
\text { er ( } 7 \\
\text { centers) }\end{array}$ & $\begin{array}{c}\text { mTLE vs. } \\
\text { extratemporal } \\
\text { epilepsy } \\
\text { (frontal, parietal, }\end{array}$ & $\begin{array}{l}\text { Epilepsy } \\
\text { surgery } \\
\text { sample }\end{array}$ & $\begin{array}{c}\text { Structural } \\
\text { MRI - T1W, } \\
\text { T2W, Coronal } \\
\text { FLAIR, }\end{array}$ & $\begin{array}{l}\text { BDI } \\
\text { CIDI }\end{array}$ & Not known & $\begin{array}{l}\text { No association with } \\
\text { lateralization and } \\
\text { localization }\end{array}$ \\
\hline
\end{tabular}




\begin{tabular}{|c|c|c|c|c|c|c|c|c|}
\hline & & & occipital) & & $\begin{array}{l}\text { Hippocampal } \\
\text { Volumetry }\end{array}$ & & & \\
\hline $\begin{array}{c}\text { Briellmann } \\
\text { et al 2007 } \\
{[28]}\end{array}$ & 34 & Australia & mTLE with HS & No SF & $\begin{array}{c}\text { Structural } \\
\text { MRI - } \\
\text { Hippocampal } \\
\text { and Amygdala } \\
\text { Volumes; } \\
\text { Tissue Signal } \\
\text { - T2 } \\
\text { Relaxometry } \\
\end{array}$ & $\begin{array}{l}\text { Psychiatric } \\
\text { assessment } \\
\text { DSM IV } \\
\text { criteria }\end{array}$ & $26.4 \%$ & $\begin{array}{l}\text { Contralateral amygdala } \\
\text { signal changes }\end{array}$ \\
\hline $\begin{array}{c}\text { Adams et al } \\
2008[30]\end{array}$ & 319 & Australia & $\begin{array}{l}\text { mTLE (HS, } \\
\text { others and non } \\
\text { lesional) vs. } \\
\text { Extratemporal } \\
\text { (lesional, non } \\
\text { lesional) }\end{array}$ & Not known & $\begin{array}{c}\text { Structural } \\
\text { MRI - } \\
\text { Laterality and } \\
\text { type of lesion }\end{array}$ & $\begin{array}{c}\text { Psychiatric } \\
\text { assessment } \\
\text { DSM IV } \\
\text { criteria }\end{array}$ & Not known & No difference \\
\hline $\begin{array}{c}\text { Richardson } \\
\text { et al 2007 } \\
{[34]}\end{array}$ & 18 & USA & TLE & $\begin{array}{c}\text { No SF } \\
44 \% \\
\text { weekly } \\
66 \% \\
\text { monthly }\end{array}$ & $\begin{array}{c}\text { Structural } \\
\text { MRI - Region } \\
\text { of Interest } \\
\text { analysis; FDG } \\
\text { PET (co- } \\
\text { registration of } \\
\text { MRI and PET } \\
\text { images) } \\
\end{array}$ & BDI & Not known & $\begin{array}{l}\text { Bilateral increased } \\
\text { amygdala volumes } \\
\text { but no changes in } \\
\text { metabolism }\end{array}$ \\
\hline $\begin{array}{l}\text { Paparrigopo } \\
\text { ulos et al } \\
\text { 2008 [77] }\end{array}$ & 35 & UK & $\begin{array}{c}\text { mTLE } \\
\text { Epilepsy surgery } \\
\text { sample }\end{array}$ & $\begin{array}{l}\text { Epilepsy } \\
\text { surgery } \\
\text { sample } \\
57 \% \text { SF }\end{array}$ & $\begin{array}{c}\text { Structural } \\
\text { MRI (post-op) } \\
- \\
\text { Hippocampal } \\
\text { and Amygdala } \\
\text { Volumetry } \\
\end{array}$ & BDI & Not known & $\begin{array}{l}\text { Post-operative } \\
\text { depression correlated } \\
\text { with the extent of } \\
\text { hippocampal and } \\
\text { amygdala resection. } \\
\text { L>R }\end{array}$ \\
\hline $\begin{array}{l}\text { Shamim et } \\
\text { al } 2009[32]\end{array}$ & 55 & USA & mTLE & Not known & $\begin{array}{c}\text { Structural } \\
\text { MRI - } \\
\text { Hippocampal } \\
\text { Volumetry }\end{array}$ & $\begin{array}{l}\text { Psychiatric } \\
\text { assessment } \\
\text { DSM IV } \\
\text { criteria } \\
\text { BDI }\end{array}$ & No patients & $\begin{array}{l}\text { RTLE low left } \\
\text { hippocampal volume } \\
\text { Left TLE no difference }\end{array}$ \\
\hline Wrench et & 83 & Australia & 26 mTLE vs. 26 & No SF & Structural & Psychiatric & $17 \%$ & mTLE \\
\hline
\end{tabular}




\begin{tabular}{|c|c|c|c|c|c|c|c|c|}
\hline al 2009 [78] & & & $\begin{array}{l}\text { extratemporal } \\
\text { focal } \\
\text { vs. } 41 \text { controls } \\
\text { Epilepsy surgery } \\
\text { sample }\end{array}$ & $\begin{array}{l}\text { extratempor } \\
\text { al TLE } \\
\text { >mTLE }\end{array}$ & $\begin{array}{c}\text { MRI - } \\
\text { Hippocampal } \\
\text { Volumetry on } \\
\text { pre-operative } \\
\text { MRI }\end{array}$ & $\begin{array}{l}\text { assessment } \\
\text { DSM-IV } \\
\text { BDI }\end{array}$ & & $\begin{array}{l}\text { Pre-operative } \\
\text { depression: No } \\
\text { association with } \\
\text { hippocampal volume } \\
\text { Post-operative } \\
\text { depression: small } \\
\text { hippocampal volumes } \\
\text { contralateral to the } \\
\text { resection. } \\
\text { Extratemporal } \\
\text { Post-operative } \\
\text { depression: no } \\
\text { association with } \\
\text { hippocampal volume }\end{array}$ \\
\hline $\begin{array}{l}\text { Van Elst et } \\
\text { al } 2009 \text { [36] }\end{array}$ & 53 & Germany & $\begin{array}{l}\text { Refractory focal } \\
\text { epilepsy } \\
\text { (temporal, } \\
\text { frontal, other } \\
\text { focal, non- } \\
\text { lesional) }\end{array}$ & No SF & $\begin{array}{l}\text { Structural } \\
\text { MRI - Region } \\
\text { of Interest } \\
\text { analysis }\end{array}$ & $\begin{array}{l}\text { Psychiatric } \\
\text { assessment } \\
\text { ICD-10 } \\
\text { criteria; } \\
\text { BDI }\end{array}$ & Excluded & $\begin{array}{l}\text { Bilateral amygdala } \\
\text { volume loss } \mathrm{R}>\mathrm{L} ;\end{array}$ \\
\hline $\begin{array}{l}\text { Salgado et } \\
\text { al } 2010 \text { [37] }\end{array}$ & 144 & Brazil & $\begin{array}{l}48 \text { mTLE vs. } 96 \\
\text { controls }\end{array}$ & No SF & $\begin{array}{c}\text { Structural } \\
\text { MRI - Voxel } \\
\text { Based } \\
\text { Morphometry }\end{array}$ & $\begin{array}{l}\text { SCID-I for } \\
\text { the DSM IV }\end{array}$ & 3 patients & $\begin{array}{l}\text { Widespread grey } \\
\text { matter volume loss } \\
\text { including bilateral } \\
\text { hippocampus, } \\
\text { parahippocampal gyrus } \\
\text { and uncus; left } \\
\text { thalamus, cuneus, and } \\
\text { fusiform gyrus; right } \\
\text { caudate body; inferior } \\
\text { and superior temporal } \\
\text { gyrus bilaterally; } \\
\text { inferior and middle } \\
\text { frontal gyrus bilaterally }\end{array}$ \\
\hline $\begin{array}{l}\text { Finegersh et } \\
\text { al } 2011 \text { [39] }\end{array}$ & 40 & USA & mTLE & Not known & $\begin{array}{l}\text { MRI with } \\
\text { radial atrophy } \\
\text { mapping (3-D }\end{array}$ & BDI & $\begin{array}{l}\text { None but } \\
\text { past } \\
\text { exposure }\end{array}$ & $\begin{array}{l}\text { Atrophy superoanterior } \\
\text { portion of the } \\
\text { hippocampus }\end{array}$ \\
\hline
\end{tabular}




\begin{tabular}{|c|c|c|c|c|c|c|c|c|}
\hline & & & & & $\begin{array}{l}\text { surface } \\
\text { modeling tool } \\
\text { to measure } \\
\text { hippocampal } \\
\text { atrophy) }\end{array}$ & & reported & $\begin{array}{l}\text { contralateral to seizure } \\
\text { focus }\end{array}$ \\
\hline $\begin{array}{l}\text { Sanchez- } \\
\text { Gistau et al } \\
2012[26]\end{array}$ & 308 & Spain & $\begin{array}{l}115 \text { mTLE with } \\
\text { HS vs. } 106 \\
\text { mTLE lesional } \\
\text { no HS vs. } 87 \\
\text { mTLE non- } \\
\text { lesional }\end{array}$ & No SF & $\begin{array}{l}\text { Structural } \\
\text { MRI }\end{array}$ & $\begin{array}{l}\text { Psychiatric } \\
\text { assessment } \\
\text { DSM-IV } \\
\text { HADS }\end{array}$ & $12.9 \%$ & HS \\
\hline $\begin{array}{l}\text { Butler et al } \\
2012[38]\end{array}$ & 81 & USA & $\begin{array}{l}36 \text { mTLE vs. } 45 \\
\text { controls }\end{array}$ & Not known & $\begin{array}{c}\text { Structural } \\
\text { MRI - Cortical } \\
\text { Thickness } \\
\text { (Whole-cortex } \\
\text { MRI } \\
\text { Morphometric } \\
\text { assessment) } \\
\end{array}$ & BDI & Not known & $\begin{array}{l}\text { Orbitofrontal cortex } \\
\text { thickening }\end{array}$ \\
\hline $\begin{array}{l}\text { Pope et al } \\
2014 \text { [79] }\end{array}$ & 30 & UK & $\begin{array}{l}\text { mTLE with LHS } \\
\text { Epilepsy surgery } \\
\text { sample }\end{array}$ & $43 \% \mathrm{SF}$ & $\begin{array}{c}\text { Structural } \\
\text { MRI - VBM } \\
\text { assessment of } \\
\text { pre-surgical } \\
\text { grey matter } \\
\text { volume } \\
\end{array}$ & $\begin{array}{l}\text { Psychiatric } \\
\text { assessment } \\
\text { DSM-IV }\end{array}$ & - & $\begin{array}{l}\text { Reduced pre-operative } \\
\text { bilateral grey matter in } \\
\text { orbitofrontal cortex, } \\
\text { ipsilateral cingulate } \\
\text { gyrus, and thalamus }\end{array}$ \\
\hline $\begin{array}{c}\text { Hecimovic } \\
\text { et al 2014 } \\
{[33]}\end{array}$ & 28 & USA & mTLE & No SF & $\begin{array}{c}\text { Structural } \\
\text { MRI - Region } \\
\text { of Interest } \\
\text { analysis } \\
\end{array}$ & BDI & Not known & $\begin{array}{l}\text { Total hippocampal } \\
\text { volumes were smaller } \\
\text { in the group with BDI } \\
<15\end{array}$ \\
\hline $\begin{array}{c}\text { Kavanaugh } \\
\text { et al 2017 } \\
{[40]}\end{array}$ & 31 & USA & $\begin{array}{l}\text { mTLE non- } \\
\text { lesional }\end{array}$ & No SF & $\begin{array}{l}\text { Diffusion } \\
\text { Tensor } \\
\text { Imaging }\end{array}$ & $\begin{array}{c}\text { MINI } \\
\text { HAM-D }\end{array}$ & $48 \%$ & $\begin{array}{l}\text { Both frontolimbic and } \\
\text { non-frontolimbic white } \\
\text { matter especially if } \\
\text { epilepsy started in } \\
\text { childhood }\end{array}$ \\
\hline Goncalves & 40 & Brazil & $\mathrm{m}$ TLE & No SF & Structural & Psychiatric & $25.8 \%$ & No difference \\
\hline
\end{tabular}




\begin{tabular}{|c|c|c|c|c|c|c|c|c|}
\hline $\begin{array}{c}\text { et al } 2017 \\
{[29]}\end{array}$ & & & & & MRI & $\begin{array}{l}\text { assessment } \\
\text { ICD-10 } \\
\text { criteria; } \\
\text { MINI } \\
\text { BDI }\end{array}$ & & \\
\hline $\begin{array}{c}\text { Rayner et al } \\
2019[31]\end{array}$ & 152 & Australia & $\begin{array}{c}19 \text { mTLE with } \\
\text { HS vs. } 30 \text { mTLE } \\
\text { lesional no HS } \\
\text { vs. } 30 \text { mTLE } \\
\text { non-lesional } \\
\text { vs. } 73 \text { Controls }\end{array}$ & NO SF & $\begin{array}{c}\text { Structural } \\
\text { MRI } \\
\text { Interictal 18F } \\
\text { FDG-PET } \\
\text { (PET } \\
\text { concordance) }\end{array}$ & $\begin{array}{c}\text { Psychiatric } \\
\text { assessment } \\
\text { DSM-IV } \\
\text { NDDI-E } \\
\text { PHQ-9 }\end{array}$ & Not known & No difference \\
\hline
\end{tabular}

\begin{tabular}{|c|c|c|c|c|c|c|c|c|}
\hline \multicolumn{9}{|c|}{ FUNCTIONAL NEUROIMAGING } \\
\hline Reference & $\begin{array}{c}\text { No of } \\
\text { patients }\end{array}$ & Country & Epilepsy type & $\begin{array}{c}\text { Seizure } \\
\text { Frequency }\end{array}$ & $\begin{array}{c}\text { Imaging } \\
\text { Technique }\end{array}$ & $\begin{array}{l}\text { Depression } \\
\text { assessment }\end{array}$ & Antidepressants & Depression correlates \\
\hline $\begin{array}{c}\text { Bonelli et } \\
\text { al } 2009 \\
{[80]}\end{array}$ & 75 & UK & $\begin{array}{c}54 \text { mTLE } \\
\text { with HS } \\
\text { vs. } 21 \\
\text { Controls } \\
\text { Epilepsy } \\
\text { surgery } \\
\text { sample }\end{array}$ & No SF & $\begin{array}{c}\text { Memory } \\
\text { encoding } \\
\text { functional } \\
\text { MRI } \\
\text { paradigm, } \\
\text { including } \\
\text { viewing } \\
\text { fearful and } \\
\text { neutral faces }\end{array}$ & HADS & Not known & $\begin{array}{l}\text { Pre-operative } \\
\text { depression: RTLE, } \\
\text { bilateral amygdala } \\
\text { activation and R } \\
\text { amygdala correlated } \\
\text { with post-operative } \\
\text { depression (not seen in } \\
\text { LTLE) }\end{array}$ \\
\hline $\begin{array}{l}\text { Chen et al } \\
2012[43]\end{array}$ & 40 & China & $\begin{array}{l}23 \text { mTLE vs. } \\
17 \text { Controls }\end{array}$ & $\begin{array}{l}\text { No difference } \\
\text { in seizure } \\
\text { frequency } \\
\text { between }\end{array}$ & $\begin{array}{l}\text { Resting state } \\
\text { functional } \\
\text { MRI }\end{array}$ & $\begin{array}{l}\text { Psychiatric } \\
\text { assessment }\end{array}$ & $\begin{array}{c}\text { Excluded } \\
\text { patients } \\
\text { receiving } \\
\text { antidepressant }\end{array}$ & $\begin{array}{l}\text { Increased activity in } \\
\text { bilateral thalami, } \\
\text { insula, caudate and } \\
\text { right anterior cingulate; }\end{array}$ \\
\hline
\end{tabular}




\begin{tabular}{|c|c|c|c|c|c|c|c|c|}
\hline & & & & $\begin{array}{l}\text { groups, all } \\
\text { seizure free for } \\
\text { at least } 15 \text {-days } \\
\text { prior to MRI }\end{array}$ & & & medications & $\begin{array}{l}\text { Decreased connectivity } \\
\text { prefrontal-limbic } \\
\text { system and increased } \\
\text { connectivity within the } \\
\text { limbic system and } \\
\text { angular gyrus }\end{array}$ \\
\hline $\begin{array}{c}\text { Kemmotsu } \\
\text { et al 2013 } \\
{[45]}\end{array}$ & 39 & USA & $\begin{array}{l}19 \text { mTLE vs. } \\
20 \text { Controls }\end{array}$ & $\begin{array}{l}\text { Not known, all } \\
\text { seizure free for } \\
\text { at least } 24- \\
\text { hours prior to } \\
\text { MRI } \\
\end{array}$ & $\begin{array}{l}\text { Volumetric } \\
\text { and } \\
\text { functional } \\
\text { connectivity } \\
\text { MRI (fcMRI) }\end{array}$ & BDI & Not & $\begin{array}{l}\text { Increased connectivity } \\
\text { frontolimbic networks; } \\
\text { Right amygdala }\end{array}$ \\
\hline $\begin{array}{c}\text { Doucet et } \\
\text { al } 2013 \\
{[41]}\end{array}$ & 41 & USA & $\begin{array}{c}22 \mathrm{~m} \text { TLE } \\
\text { with HS vs. } \\
19 \text { controls }\end{array}$ & Not known & $\begin{array}{c}\text { Functional } \\
\text { MRI - } \\
\text { Functional } \\
\text { connectivity } \\
\text { emerging } \\
\text { from } \\
\text { Amygdala } \\
\end{array}$ & $\begin{array}{l}\text { Personality } \\
\text { Assessment } \\
\text { Inventory } \\
\text { (PAI) } \\
\text { based on } \\
\text { the DSM }\end{array}$ & $17 \%$ & $\begin{array}{l}\text { Opposite functional } \\
\text { connectivity }\end{array}$ \\
\hline $\begin{array}{c}\text { Kemmotsu } \\
\text { et al } 2014 \\
{[44]}\end{array}$ & 41 & USA & $\begin{array}{l}21 \text { mTLE vs. } \\
20 \text { controls }\end{array}$ & $\begin{array}{l}\text { Seizures per } \\
\text { month recorded }\end{array}$ & $\begin{array}{l}\text { Functional } \\
\text { MRI - } \\
\text { Diffusion } \\
\text { Tensor } \\
\text { Imaging }\end{array}$ & BDI & $2.4 \%$ & $\begin{array}{l}\text { Both L and R TLE } \\
\text { microstructural } \\
\text { compromise to the } \\
\text { uncinate fasciculus } \\
\text { LTLE: ipsilateral } \\
\text { hippocampus and } \\
\text { anterior-prefrontal } \\
\text { cortex; }\end{array}$ \\
\hline $\begin{array}{l}\text { Stretton et } \\
\text { al } 2015 \\
{[47]}\end{array}$ & 78 & UK & $\begin{array}{l}48 \text { mTLE vs. } \\
30 \text { controls }\end{array}$ & Not known & $\begin{array}{l}\text { Functional } \\
\text { MRI } \\
\text { (visuospatial } \\
\text { 'n-back' } \\
\text { paradigm to } \\
\text { compare } \\
\text { working } \\
\text { memory } \\
\text { between } \\
\text { groups) }\end{array}$ & $\begin{array}{l}\text { Psychiatric } \\
\text { assessment } \\
\text { DSM IV- } \\
\text { TR; } \\
\text { BDI-Fast } \\
\text { Screen }\end{array}$ & $6.4 \%$ & $\begin{array}{l}\text { Lifetime depression: } \\
\text { deactivation in } \\
\text { subgenial anterior } \\
\text { cingulate cortex } \\
\text { (sACC); No significant } \\
\text { differences in grey } \\
\text { matter volume or } \\
\text { structural connectivity }\end{array}$ \\
\hline
\end{tabular}




\begin{tabular}{|c|c|c|c|c|c|c|c|c|}
\hline & & & & & $\begin{array}{c}\text { Structural - } \\
\text { Voxel Based } \\
\text { Morphometry } \\
\text { and Diffusion } \\
\text { Tensor } \\
\text { Imaging }\end{array}$ & & & \\
\hline $\begin{array}{l}\text { Zhu et al } \\
2018[46]\end{array}$ & 56 & China & $\begin{array}{c}35 \text { mTLE } \\
\text { non-lesional } \\
\text { vs. } 21 \\
\text { Controls }\end{array}$ & Not known & $\begin{array}{l}\text { Resting state } \\
\text { functional } \\
\text { MRI }\end{array}$ & $\begin{array}{l}\text { Psychiatric } \\
\text { assessment } \\
\text { DSM IV } \\
\text { HAM-D }\end{array}$ & None & $\begin{array}{l}\text { Bilateral mesial } \\
\text { prefrontal cortex, } \\
\text { precuneus, angular } \\
\text { gyrus, right } \\
\text { parahippocampal gyrus } \\
\text { and right temporal pole } \\
\text { (prefrontal-limbic } \\
\text { system) }\end{array}$ \\
\hline $\begin{array}{l}\text { Peng et al } \\
2018[42]\end{array}$ & 47 & China & $\begin{array}{l}32 \text { mTLE vs. } \\
15 \text { Controls }\end{array}$ & No SF & $\begin{array}{l}\text { Resting state } \\
\text { functional } \\
\text { MRI }\end{array}$ & HAM-D & None & $\begin{array}{l}\text { Bilateral cerebellum; } \mathrm{R} \\
\text { hippocampus }\end{array}$ \\
\hline $\begin{array}{c}\text { Garcia et } \\
\text { al } 2019 \\
{[48]}\end{array}$ & 112 & Brazil & $\begin{array}{l}74 \text { Genetic } \\
\text { Generalized } \\
\text { Epilepsy } \\
(\text { JME }=54 \\
\text { JAE }=11 \\
\text { GTCS only = } \\
\text { 9) vs. } 38 \\
\text { Controls }\end{array}$ & $\mathrm{SF}=12$ & $\begin{array}{l}\text { 3T resting } \\
\text { state } \\
\text { functional } \\
\text { MRI } \\
\text { (volumetric } \\
\text { T1W and } \\
\text { resting state) }\end{array}$ & BDI & Not known & $\begin{array}{l}\text { Default mode network; } \\
\text { left executive control } \\
\text { network, salience, and } \\
\text { visuospatial attention }\end{array}$ \\
\hline
\end{tabular}

\section{PHARMACO AND METABOLIC NEUROIMAGING}

\begin{tabular}{|l|c|c|c|c|c|c|c|c|}
\hline Reference & $\begin{array}{c}\text { No of } \\
\text { patients }\end{array}$ & Country & $\begin{array}{c}\text { Epilepsy } \\
\text { type }\end{array}$ & $\begin{array}{c}\text { Seizure } \\
\text { Frequency }\end{array}$ & $\begin{array}{c}\text { Imaging } \\
\text { Technique }\end{array}$ & $\begin{array}{c}\text { Depression } \\
\text { assessment }\end{array}$ & Antidepressants & $\begin{array}{c}\text { Depression } \\
\text { Correlates }\end{array}$ \\
\hline Bromfield & 49 & USA & 23 mTLE & No SF & FDG PET & Psychiatric & Not known & Bilateral \\
\hline
\end{tabular}




\begin{tabular}{|c|c|c|c|c|c|c|c|c|}
\hline $\begin{array}{c}\text { et al } 1992 \\
{[53]}\end{array}$ & & & $\begin{array}{c}\text { vs. } 26 \\
\text { Controls }\end{array}$ & & $\begin{array}{c}18-\mathrm{F}-2- \\
\text { deoxyglucose } \\
\text { positron emission } \\
\text { tomography }\end{array}$ & $\begin{array}{l}\text { assessment; } \\
\text { BDI; }\end{array}$ & & $\begin{array}{l}\text { reduction in } \\
\text { inferior frontal } \\
\text { glucose } \\
\text { metabolism } \\
\end{array}$ \\
\hline $\begin{array}{c}\text { Victoroff } \\
\text { et al } 1994 \\
{[54]}\end{array}$ & 53 & USA & mTLE & Not known & 18 FDG PET & $\begin{array}{l}\text { Semi structured } \\
\text { neuropsychiatric } \\
\text { interview using } \\
\text { structured } \\
\text { clinical } \\
\text { interview for } \\
\text { DSM-III-R } \\
\text { HAM-D } \\
\end{array}$ & Not known & $\begin{array}{l}\text { L temporal } \\
\text { hypometabolism }\end{array}$ \\
\hline $\begin{array}{l}\text { Ring et al } \\
1999 \text { [49] }\end{array}$ & 19 & $\overline{\mathrm{UK}}$ & mTLE & $\begin{array}{c}\text { No SF } \\
\text { No seizures } \\
\text { for at least 24- } \\
\text { hours before } \\
\text { imaging }\end{array}$ & $\begin{array}{l}\text { SPECT scan using } \\
\text { 99mTc-HMPAO } \\
\text { (blood flow } \\
\text { marker) }\end{array}$ & $\begin{array}{l}\text { Psychiatric } \\
\text { assessment } \\
\text { DSM IIIR and } \\
\text { IV criteria } \\
\text { HAM-D }\end{array}$ & $21 \%$ & $\begin{array}{l}\text { Increased } \\
\text { perfusion left } \\
\text { frontal, } \\
\text { temporal, } \\
\text { parietal and } \\
\text { subcortical } \\
\text { structures }\end{array}$ \\
\hline $\begin{array}{c}\text { Schmitz } \\
\text { et al 1999 } \\
{[50]}\end{array}$ & 31 & UK & $\begin{array}{c}\text { Focal } \\
\text { epilepsy } \\
\text { Left }=13 \\
\text { Right }=18\end{array}$ & Not known & $\begin{array}{l}\text { 99M Tc-HMPAO } \\
\text { SPECT (cerebral } \\
\text { blood flow) }\end{array}$ & BDI & None & $\begin{array}{l}\text { Low } \\
\text { contralateral } \\
\text { temporal and } \\
\text { bilateral frontal } \\
\text { perfusion and } \\
\text { higher occipital } \\
\text { perfusion; }\end{array}$ \\
\hline $\begin{array}{c}\text { Salzberg } \\
\text { et al } 2006 \\
{[81]}\end{array}$ & 23 & Australia & $\begin{array}{l}\text { mTLE } \\
\text { Epilepsy } \\
\text { surgery } \\
\text { sample }\end{array}$ & - & $\begin{array}{c}\text { FDG PET } \\
\text { 18-F-2- } \\
\text { deoxyglucose } \\
\text { positron emission } \\
\text { tomography }\end{array}$ & $\begin{array}{l}\text { Psychiatric } \\
\text { assessment - } \\
\text { DSM IV }\end{array}$ & $8.7 \%$ & $\begin{array}{l}\text { Hypometabolism } \\
\text { ipsilateral } \\
\text { orbitofrontal } \\
\text { cortex }\end{array}$ \\
\hline $\begin{array}{c}\text { Hasler et } \\
\text { al } 2007 \\
{[56]}\end{array}$ & 37 & USA & mTLE & Not known & $\begin{array}{c}{[18 \mathrm{~F}]-\mathrm{FCWAY}} \\
\text { PET looking at 5- } \\
\text { HT1 A receptor } \\
\text { binding } \\
\text { Structural MRI }\end{array}$ & $\begin{array}{l}\text { Psychiatric } \\
\text { assessment - } \\
\text { DSM IV }\end{array}$ & Excluded & $\begin{array}{l}\text { Reduction in 5- } \\
\text { HT1A receptor } \\
\text { binding in } \\
\text { anterior } \\
\text { cingulate, right }\end{array}$ \\
\hline
\end{tabular}




\begin{tabular}{|c|c|c|c|c|c|c|c|c|}
\hline & & & & & & & & $\begin{array}{l}\text { hippocampus } \\
\text { and medial and } \\
\text { superior } \\
\text { temporal gyrus }\end{array}$ \\
\hline $\begin{array}{c}\text { Gilliam et } \\
\text { al 2007 } \\
\text { [51] }\end{array}$ & 31 & USA & mTLE & $\begin{array}{c}\text { No SF CPS, } \\
\text { GTCS }\end{array}$ & $\begin{array}{l}\text { 1H-Magnetic } \\
\text { Resonance } \\
\text { Spectroscopic } \\
\text { Imaging (1H- } \\
\text { MRSI) - using } \\
\text { Creatine/ N- } \\
\text { Acetylaspartate } \\
\text { (Cr/ NAA) maps }\end{array}$ & POEMS & Not known & $\begin{array}{l}\text { Abnormal } \\
\text { hippocampal } \\
\text { metabolism and } \\
\text { Cr/ NAA ratio }\end{array}$ \\
\hline $\begin{array}{c}\text { Theodore } \\
\text { et al } 2007 \\
{[55]}\end{array}$ & 55 & USA & $\begin{array}{l}45 \text { mTLE } \\
\text { vs. } 10 \\
\text { Controls }\end{array}$ & $\begin{array}{l}\text { Not known } \\
\text { None had } \\
\text { seizures for at } \\
\text { least 2-days } \\
\text { before PET } \\
\text { scanning }\end{array}$ & $\begin{array}{l}\text { [[18F]-FCWAY } \\
\text { PET looking at 5- } \\
\text { HT1A receptor } \\
\text { binding } \\
\text { Structural MRI }\end{array}$ & BDI & Excluded & $\begin{array}{l}\text { Inverse relation } \\
\text { with ipsilateral } \\
\text { hippocampal } \\
\text { binding } \\
\text { (according to } \\
\text { severity of } \\
\text { symptoms }\end{array}$ \\
\hline $\begin{array}{c}\text { Lothe et } \\
\text { al } 2008 \\
{[58]}\end{array}$ & 24 & France & $\begin{array}{l}\text { mTLE with } \\
\text { HS } \\
\text { Epilepsy } \\
\text { surgery } \\
\text { sample }\end{array}$ & $\begin{array}{c}71 \% \\
\text { underwent } \\
\text { surgery - 94\% } \\
\text { Engel Class } 1\end{array}$ & $\begin{array}{c}{[18 \mathrm{~F}]-\mathrm{MPPF} \text { PET }} \\
\text { which is a 5-HT1A } \\
\text { antagonist - Voxel } \\
\text { based and Region } \\
\text { of Interest } \\
\text { analyses }\end{array}$ & $\begin{array}{c}\text { Psychiatric } \\
\text { assessment - } \\
\text { DSM IV; } \\
\text { BDI-II }\end{array}$ & Excluded & $\begin{array}{l}\text { Cognitive } \\
\text { symptoms and } \\
\text { anhedonia -> } \\
\text { raphe nuclei and } \\
\text { insula } \\
\text { contralateral to } \\
\text { seizure onset; } \\
\text { Somatic } \\
\text { symptoms -> } \\
\text { hippocampal/ } \\
\text { parahippocampal } \\
\text { region ipsilateral } \\
\text { to seizure onset, } \\
\text { left mid- } \\
\text { cingulate gyrus, } \\
\text { inferior }\end{array}$ \\
\hline
\end{tabular}




\begin{tabular}{|c|c|c|c|c|c|c|c|c|}
\hline & & & & & & & & $\begin{array}{l}\text { dorsolateral } \\
\text { frontal cortex } \\
\text { bilaterally }\end{array}$ \\
\hline $\begin{array}{c}\text { Assem- } \\
\text { Hilger et } \\
\text { al 2010 } \\
{[59]}\end{array}$ & 26 & Austria & $\begin{array}{l}13 \text { mTLE } \\
\text { vs. } 13 \\
\text { Controls }\end{array}$ & Not known & $\begin{array}{c}\text { PET using } \\
\text { [carbonyl- } \\
\text { 11C]WAY- } \\
100635 \text { (serotonin } \\
\text { 1A 5-HT 1A } \\
\text { receptor } \\
\text { antagonist) } \\
\end{array}$ & $\begin{array}{c}\text { HAM-D } \\
\text { BDI }\end{array}$ & None & No association \\
\hline $\begin{array}{c}\text { Theodore } \\
\text { et al 2012 } \\
\text { [57] }\end{array}$ & 40 & USA & mTLE & $\begin{array}{l}\text { Not known } \\
\text { None had } \\
\text { seizures for at } \\
\text { least 2-days } \\
\text { before PET } \\
\text { scanning } \\
\end{array}$ & $\begin{array}{l}\text { [[18F]-FCWAY } \\
\text { PET looking at 5- } \\
\text { HT1A receptor } \\
\text { binding } \\
\text { Structural MRI } \\
\end{array}$ & BDI & Not known & $\begin{array}{l}\text { Inverse relation } \\
\text { ipsilateral focus; } \\
\text { No difference } \\
\text { between R and L }\end{array}$ \\
\hline $\begin{array}{c}\text { Martinez } \\
\text { et al 2013 } \\
\text { [60] }\end{array}$ & 29 & USA & $\begin{array}{l}13 \text { mTLE } \\
\text { vs. } 16 \\
\text { Controls }\end{array}$ & Not known & $\begin{array}{c}\text { [[18F]-FCWAY } \\
\text { PET looking at 5- } \\
\text { HT1A receptor } \\
\quad \text { binding } \\
\begin{array}{c}\text { [11C]-DASB PET } \\
\text { looking for 5-HTT } \\
\text { (transporter) }\end{array} \\
\text { Structural MRI }\end{array}$ & $\begin{array}{l}\text { Psychiatric } \\
\text { assessment - } \\
\text { DSM IV; } \\
\text { BDI-II }\end{array}$ & $\begin{array}{c}1 \text { patient had } \\
\text { been taking } \\
\text { fluoxetine until } \\
\text { 2-months before } \\
\text { study }\end{array}$ & $\begin{array}{l}\text { Reduced 5-HTT } \\
\text { in insula and } \\
\text { fusiform gyrus }\end{array}$ \\
\hline $\begin{array}{l}\text { Liik et al } \\
2013[61]\end{array}$ & 12 & Estonia & $\begin{array}{l}7 \text { Focal; } 5 \\
\text { Generalized }\end{array}$ & No SF & $\begin{array}{l}\text { Single Photon } \\
\text { Emission } \\
\text { Tomography } \\
\text { (SPET) using } \\
\text { SERT radioligand } \\
\text { 123I-ADAM } \\
\text { (serotonin } \\
\text { transporter) } \\
\end{array}$ & BDI & None & No difference \\
\hline $\begin{array}{l}\text { Peng et al } \\
2013 \text { [52] }\end{array}$ & 50 & China & $\begin{array}{l}\text { Mix of } \\
\text { various }\end{array}$ & $\begin{array}{l}\text { No difference } \\
\text { in seizure }\end{array}$ & $\begin{array}{c}\text { Single-voxel } \\
\text { proton magnetic }\end{array}$ & HAM-D & Excluded & $\begin{array}{l}\text { Increased Glx/ } \\
\text { Cr right }\end{array}$ \\
\hline
\end{tabular}




\begin{tabular}{|l|l|l|l|c|c|l|l|l|}
\hline & & types & $\begin{array}{c}\text { frequency } \\
\text { between } \\
\text { groups. No } \\
\text { seizures for at } \\
\text { least 7-days } \\
\text { before } \\
\text { imaging }\end{array}$ & $\begin{array}{c}\text { resonance } \\
\text { spectroscopy (1H- } \\
\text { MRS) }\end{array}$ & & & & \\
& & & & & \\
\end{tabular}

mTLE = mesial temporal lobe epilepsy; lTLE= lateral temporal lobe epilepsy; $\mathrm{R}=$ right; $\mathrm{L}=\mathrm{left} ; \mathrm{HS}=$ hippocampal sclerosis; $\mathrm{SF}=\mathrm{seizure}$ free; BTC=bilateral tonic clonic seizures; BDI=Beck Depression Inventory; HAM-D: Hamilton Depression Rating Scale; HADS: Hospital Anxiety Depression Scale; DSM= Diagnostic and statistical manual of mental disorders; NDDIE= Neurological Disorders Depression Inventory for Epilepsy; SCID-I= Structured Clinical Interview for DSM Axis I; CIDI=Composite International Diagnostic Interview; MINI= Mini International Neuropsychiatric Inventory 